essential for conservation to have the proper scientific basis' and that of Dr Bourne that 'it is still sometimes important for purposes of both conservation and the advancement of knowledge that examples of potential new forms should be placed on record as soon as possible', as well as Dr Hutterer's claim that 'to obtain the primary information, collection of specimens is often required'.

The point I was, apparently unsuccessfully, endeavouring to make, was that the advent of deoxyribonucleic acid (DNA) genetic 'fingerprinting', coupled with modern photographic, videotaping and sound-recording techniques, makes it perfectly possible to demonstrate the existence of new forms without the necessity of resorting to the collection of living specimens of possibly threatened species. The notion that to prove and establish the existence and identity of a species new to science it is necessary to collect a holotype is, I submit, outdated.

Christopher Lever, Newell House, Winkfield, Windsor, Berkshire SL4 4SE, UK.

\section{Cat amongst the freiras}

Since early 1987 the Madeira-based team of the Freira Conservation Project has carried out aggressive poisoning of the black rat Rattus rattus in the breeding area of the endemic Madeira freira Pterodroma madeira, using Klerat provided by ICI. The scheme has met with success and while no juveniles were recorded at the start of the project, the number of successfully fledged juveniles has increased over the years.

At the onset of the 1991 breeding season things augured well; the birds returned to their breeding grounds and were observed cleaning out their burrows. The first warning of trouble came in late June, when what appeared to be a dead bird was observed through binoculars on a breeding ledge. This exceptionally dangerous site was eventually visited on 1 July 1991. To our horror the remains of eight freiras were found and on a subsequent visit, two more, making a total of 10 dead freiras. If we consider these as breed- ing birds, from an estimated breeding population of 20-30 pairs, then the magnitude of the problem can be seen.

Almost certainly the culprit of this slaughter is a cat. Feral cats have been observed in the area and scats recovered, which contained white feathers. How to rid the area of cats in such wild terrain with unlimited cover is a major problem that must be overcome at all costs. I would welcome any advice on how to tackle this problem.

Francis Zino, Freira Conservation Project, Avenida do Infante 26, Rez-do-Chäo C, 9000 Funchal, Madeira.

\section{Lake Nakuru Black Rhinoceros Sanctuary}

I would like to comment on the article, Lake Nakuru Black Rhinoceros Sanctuary (Oryx, 24, 90-94).

This sanctuary was always intended as a sanctuary for both black and white rhinos, and although the article was about the black rhino, and probably at the time the article was written only black rhino were present in the sanctuary, this point should have been mentioned. Some years earlier the UK press had stated that the remaining government-owned white rhino had been killed at Meru Park after the Warden, Mr Peter Jenkins, had left there, and stated that these had been the last in Kenya. In fact, at that time, I was Warden at Solio Game Reserve and we had very healthy populations of both black and white rhinos. It was, indeed, due to excess numbers of both species that the Rhino Rescue started. Solio was the only place in Kenya free from poaching and over the previous 14 years the populations of both species had steadily increased to the point that Peter Jenkins and I decided to take action to relieve the pressure and set up rhino sanctuaries elsewhere. Peter was, at that time stationed at Mweiga Park Headquarters of the Aberdare Park, not far from Solio. Once the government Wildlife Conservation and Management Service started trapping, word got out about the large numbers of rhino in Solio and poaching began. 
In the introduction to the article it was stated that 17 animals came from Solio; in fact 15 came from Solio. When the reserve was started there were 19 rhinos present: 15 from Solio, two from the Conservation Department and two survivors from the original park stock. The statement that 'a further 11 females are due to be added to the park shortly', is pure speculation. In fact 6 white rhinos had been promised by Mr Parfet, owner of Solio, for the Reserve, free, at a meeting held before any captures started, and of these, at this date two have arrived. The only person who might have had knowledge of future intentions was Dr Dietter Rottcher, who affected the captures, or the Director, and both were likely to be following my principle of saying as little as possible to reduce the risk of poaching.

On page 91 the figure quoted of 700 volts is inaccurate: around 7000 is aimed at, although often 3000 has to be accepted. Also on page 91 it was stated that rhinos were acclimatized in holding pens before being released into the sanctuary. In fact, all the rhinos caught at Solio were crate-trained there before being crated and released via a ramp directly into the sanctuary. The only rhinos kept in holding pens at Nakuru before release were animals that had been wounded in fights in the reserve or in transit and needed veterinary attention before release.

On page 93 it was stated that, "The founding stock was deliberately kept low to encourage the animals to breed more freely'. This was never true for black rhinos, which were taken from anywhere all the time. As Warden I had to accept this because the alternative was that they would probably be poached. In fact, I instituted the capture of black rhino from an adjoining ranch, which was being taken over for settlement, and I managed to get the owner of Solio Reserve for the first time to take females only, by pointing out that the reserve aready had too many males. The balnce was moved to Aberdare Park because Solio already had the highest density of rhinos in Africa and they were degrading their own habitat.

On page 94 it was stated that 19 black rhinos were present at the time the article was written, with one calf having been born since the sanctuary formed. This must be incorrect because there were 19 rhinos present as the founding stock and no death had been mentioned.

I enjoyed reading the article but was disappointed about the inaccuracies. I am aware that these were probably not the author's fault at all but that he was given false information by other people and that he did not check facts with those directly involved with the operations. I am still visiting and reporting on Nakuru for the Rhino Coordinating Officer of the Kenya Wildlife Service.

R. T. Elliott, clo Ndume Ltd, Box 62, PO Gilgil, Kenya.

\section{Poisoning rhinos and tigers in Nepal}

May I, on behalf of the International Trust for Nature Conservation, add a footnote to the interesting article by Esmond Bradley Martin, 'The poisoning of rhinos and tigers in Nepal' (Oryx, 26, 82-86).

He refers, in the section "The future - funding', to a contribution made by this Trust towards efforts made in Nepal to combat the problem that he describes so eloquently. The sum he mentions is in fact a monthly payment, which we have made since Janaury 1991 to the Warden of Chitwan National Park. This covers the costs of the special anti-poaching measures that he has introduced. In addition, the Trust has also undertaken to pay (via the Park Warden) a reward of Rs50,000 (about $\$ 1675)$ to anyone providing information leading to the arrest of one or more poachers.

The ITNC is a private, non-member charity with a fairly low public profile in the UK but we have been actively involved in wildlife conservation for some years, particularly in Nepal. Among our past projects we supported Dr Laurie's study of the greater one-horned rhinoceros in the Chitwan as well as other research and campaigning activities focused on this species.

F. A. J. Hawkins, Secretary to ITNC, c/o Assistant Director, RG S, 1 Kensington Gore, London SW7 2AR, UK. 